\title{
IMBALANCE OF THE PUBLIC FINANCE IN THE CONTEXT OF KEYNESIAN AND NONKEYENSIAN EFFECTS OF FISCAL POLICY LIMITATION
}

\author{
Joanna Stawska \\ University of Lodz \\ 39 Rewolucji 1905 Street \\ Lodz, 90-214, Poland \\ $(+48) 426355249$ \\ joanna.stawska@uni.lodz.pl
}

\begin{abstract}
The purpose of this article is to point out the importance of the size of public debt and deficit in the context of Keynesian and non-Keynesian effects of fiscal policy limit. To achieve this objective primarily were used methods of analysis of the available literature and presentation of statistical data. Considerations include, among others, the presentation of public debt and deficit in the context of economic growth. Expansionary fiscal policy often caused by economic fluctuations contributes to the deepening of public finance imbalance with frequent decline in GDP growth. The restrictive policy influences on improving the situation of the public finance sector in the long-term with at least moderate economic growth.
\end{abstract}

Keywords: fiscal policy, public finance imbalance, financial crisis

\section{Introduction}

In the economy, there are mechanisms that cause the budget deficit is formed in a pro-cyclical way [1], [2]. This is a relatively common phenomenon. As shown by empirical research, as far as fiscal policy in developing countries tends to be pro-cyclical, so in the G7 countries, fiscal policy is conducted in a rather anti-cyclical way [3]. Similar results of studies conducted on different samples reached the Lane [4], Alesina, Tabellini [5] and others. C. Adam and D. Bevan indicate that sustained in the long term budget deficit contributes to a slowdown in economic growth [6]. C.Reinhart and K.Rogoff give significant results of the analysis covering 44 countries highly economically developed and developing countries. In their opinion, the high level of public debt in relation to GDP (over 90\%) is associated with lower levels of GDP growth [7]. Disputes about the negative or positive impact of the public finance imbalance on the growth are taking place for many years, but recently has been intensified. Hence, the purpose of this article is to point out the importance of the size of the general government debt in the context of Keynesian and non-Keynesian effects of fiscal policy limitation.

\section{Reflections on Keynesian and NonKeynesian effects of limiting public finances}

Public debt is a consequence of the budget deficit (a negative balance of the consolidated balance sheet of the public sector). The literature mentions several reasons for the budget deficit among others: 1) between budgetary expenditure and revenue from taxes and other sources, there is a lack of synchronization; 2) too extended functions of the state; 3 ) between the tax burdens which do not reduce the rate of economic growth and the size of government spending is difficult to find the optimum relationship; 4) adverse demographic trends; 5) use of fiscal intervention in the conditions of economic recession, for example: "Fiscal packages"; 6) often politicians in preelection declarations consist society promises that at the moment of require of funds they are higher than obtained in a natural manner through taxes;7) over developed welfare state mainly in relation to GDP growth and ability to raise budget revenues (excessive social policy, social privileges) [8]. Occurring in the economy, the budget deficit and public debt impact on economic growth in different ways. Many economists have on this completely different opinion and theories. One of the popular models describing the influence of Keynesian demand of the public sector on economic growth is P. Samuelson model. Based on the model it was noted that the increase in demand of the public sector contributes to GDP growth, while the decline in the demand by tightening fiscal policy to drop the product. In this model, it is assumed that the total demand is below the potential level, and the prices have excellent rigidity. Hence with such assumptions the aggregate demand determines the amount of product in the economy. Therefore, higher public spending ceteris paribus cause an increase in global demand and product, and lower public spending, ceteris paribus, lead to a decline in global demand and product. In addition, in the model Samuelson is pointed out that the increase in savings contributes to the decline in demand, ceteris paribus, a decline in savings causes an increase in demand, this is called. the paradox of savings. Model Samuelson and other Keynesian models are used in the analysis of economic processes in the short term. As a result of fiscal expansion (increase in budgetary expenditure), occurs the output growth in the short term - but this does not mean growth in the long term. This is due to the fact that economic growth in the long term, influenced by fiscal factors such as : the structure of public expenditure, the level of public spending, the amount and types of taxes and the scale of imbalances in public finances [9]. In the 80 s of the twentieth century, there have appeared studies on the positive effect of reducing public spending or raise taxes on the growth of aggregate demand in the short term. These studies related to non-Keynesian effects of fiscal tightening that can occur when public finances stand before the crisis, taxes are high and despite the public debt is growing rapidly. It turns out, however, that to 
appearance the Keynesian effects may lead the sufficiently strong deficit reduction. In the literature, there are also opinions that the occurrence of non-Keynesian effects of the tightening of fiscal policy significantly influenced not the size of the original imbalances in public finances but rather a way of their reduction. Deficit reduction may be accompanied by acceleration of the product, not by raising taxes, but by cuts in expenditure, mainly in spending on public sector wages and social transfers [10]. An interesting model describing non-Keynesian effects of fiscal tightening is, among others, model O. J. Blanchard (1985.1990) [11], [12]. This model connects nonKeynesian effects with changes in the uncertainty felt by households caused by fiscal impulses. In this model, the probability of the occurrence of uncertainty of households is addicted to not only the rate of tax burden and public debt levels but also on the degree of development of the financial system or the horizon of maximizing of the utility by the household [9]. Analyzing the assumptions of Blanchard model should be noted that households may have a certain myopia that results from continuous risk of death or expiration of the family, or the underdevelopment of the financial system, which in turn prevents the smoothing consumption over time. Decisions taken by households are within the range of choices from the Keynesian (only the current period) to the Ricardian (infinite time horizon). Among the assumptions in the model is also listed zero level of tax rate, which the exceeding result in the permanent decline of the product. Moreover, in each period the probability of carrying out consolidation of public finances is the same. The consolidation is understood as a reduction of the deficit, which will affect the stabilization of the public debt in relation to the product. Taking this into account, tax increase produces two effects: a) First of all it is related to the increase in the expected value of lifelong household assets, which determines their consumption possibilities. It also allows you to stop the accumulation of public debt to the size at which it would be necessary to raise tax rates to a level causing abnormal lowering the product; b) Tax increase ensures households in the current period that taxes will not increase in the future above the critical level. However, such an increase, assuming maximizing the utility by households in a finite time horizon, is the same as the increase in the expected value of the total tax burden. With the deposition of consolidation are increasing the chances of at least a partial shift of the debt cost for the next generation. As a result, the first effect dominates the effect of the other. This is due to the fact that tax increase contributes to the growth of private consumption and aggregate demand only in extraordinary circumstances - i.e. when bringing closer an extraordinary expense in the process of balancing public finances (public debt reaches high levels and still increases despite the tax rate close to the critical value). $\Lambda$. Rzonca adds that the range of tax rates, in which achieve fiscal balance as a result of tax increases could lead to an increase in private consumption, is relatively narrow [10]. Based on the model of Blanchard it can be concluded that the fiscal tightening rarely may lead to non-Keynesian effects, so to an increase in aggregate demand. In order for that to happen, the rate of tax burden and public debt should be at a sufficiently high level. Then a further tax increase may contribute to nonKeynesian effects [13]. Among other Alesina and Perotti [14]; Alesina and Ardagna [15] or Alesina, Ardagna, Perotti and Schiantarelli [16], who conducted empirical research on non-keynesian effects of fiscal tightening, emphasized that the increase in aggregate demand in the time of consolidation of public finances seems more likely if they are balanced by cuts in public spending and not by raising taxes. On the base of the modified model of Blanchard can be concluded that the probability of non Keynesian effects of fiscal tightening is higher in countries where: 1) the financial condition is bad, the public debt is substantial and it continues to grow despite high taxes; 2) Households are aware of the impossibility of postponing fiscal consolidation and thus they know about the negative consequences for the level of the product by raising taxes; 3 ) the persons responsible for fiscal policy - according to households - as the only form of balancing the budget they see an increase in taxes (and not a limitation of expenditure); 4) as a result, the government surprises households and reduces the level of state spending. Thus, the reduction of public expenditure does not mean worse results than a tax increase. [13] In the short term reduction of the deficit in public finances may reduce the rate of economic growth but not always which is indicated by the theory and empiricism.

\section{Analysis of economic situation in Poland, with particular emphasis on public finances}

Recent economic and financial crisis, which began in 2008 contributed to the need to pay attention to the public finances of many countries. Typically, the tendency to increase budget deficits and debts of public finances are intensified by the recession phenomena. In order to analyze the situation of public finances and the size of the economic growth in Poland, are presented in Table 1 of revenue, government expenditure and the general government deficit and GDP in Poland in the years 20002014 in current prices.

Table 1 Public finances revenues and expenditure, General Government deficit and GDP in million zloty, in Poland

\begin{tabular}{c|c|c|c|c}
\hline Year & $\begin{array}{c}\text { Public } \\
\text { finances } \\
\text { revenue_nomi } \\
\text { nal }\end{array}$ & $\begin{array}{c}\text { Public } \\
\text { finances } \\
\text { expenditure } \\
\text { nominal }\end{array}$ & $\begin{array}{c}\text { GEF_nomi } \\
\text { nal }\end{array}$ & $\begin{array}{c}\text { GDP_nom } \\
\text { inal }\end{array}$ \\
\hline 2000 & 271641,9 & 293115,8 & -22194 & 747032 \\
\hline 2001 & 291491,0 & 329682,6 & -37309 & 779975 \\
\hline 2002 & 304822,9 & 351064,8 & -39280 & 810617 \\
\hline 2003 & 319955,5 & 365252,8 & -51408 & 845930 \\
\hline 2004 & 345933,7 & 387834,6 & -47796 & 927306 \\
\hline 2005 & 382496,8 & 412130,7 & -39288 & 984919 \\
\hline 2006 & 420411,1 & 442609,5 & -38228 & 1065209 \\
\hline 2007 & 484853,3 & 483182,4 & -21972 & 1186773 \\
\hline 2008 & 515204,6 & 535837,6 & -46369 & 1277322 \\
\hline 2009 & 539890,2 & 590019,8 & -99666 & 1361850 \\
\hline 2010 & 551098,5 & 635774,3 & -109728 & 1437357 \\
\hline 2011 & 604203,0 & 660082,1 & -76174 & 1553582 \\
\hline 2012 & 651121,5 & 689280,6 & -60433 & 1615894 \\
\hline
\end{tabular}




\begin{tabular}{l|l|l|l|l}
\hline 2013 & 650315,1 & 699177,5 & -66735 & 1662052 \\
\hline 2014 & 677159,0 & 716857,5 & -55241 & 1724723 \\
\hline
\end{tabular}

The largest increase in the deficit of the general government in Poland took place during the financial crisis in the years 2009 - 2010. Then the increase in spending was much higher than the increase in public revenues. In the years 2000 - 2014 only two times the general government deficit was below $3 \%$, which meant meeting the fiscal rules. In Poland there are fiscal rules contained at international level, namely the Treaty on European Union (Maastricht Treaty) of 7 February 1992 and the accompanying Protocol on the excessive deficit procedure. They set the maximum level of public debt at $60 \%$ of GDP at market prices and the deficit at 3\% of GDP at market prices [17]. On the other hand, national fiscal rules have been enshrined in the Constitution of Republic of Poland of 1997 and in the Public Finance Act. In the Constitution was placed a provision that prohibits the granting of loans or guarantees and financial sureties in the aftermath, the amount of public debt would exceed 3/5 of GDP [18]. Similarly, the Public Finance Law stipulates that the public debt cannot exceed $60 \%$ of the annual GDP [19]. In periods of decline in GDP in the economy were also noticeable increases in deficits of general government (although the increase in the deficit of public finances was a factor mitigating the impact of the crisis on the Polish economy). In 2009 this deficit was $7.3 \%$ of GDP and in 2010 already $7.6 \%$ of GDP. This debt began to fall in 2011 from $4.9 \%$ of GDP to $3.2 \%$ of GDP in 2014 (Table 2). The increase in the deficit of public finances among others, had its roots in the activities of anti-crisis measures of the government. Fiscal authorities reduced the burden on social security contributions, tax and administrative barriers, and increased spending on public investment.

Table 2 General Government debt and deficit and GDP growth (\% GDP) in Poland

\begin{tabular}{c|c|c|c}
\hline Year & GG debt & GG deficit & GDP growth \\
\hline 2000 & $-36,5$ & 2,97 & 4,3 \\
\hline 2001 & $-37,3$ & 4,78 & 1,2 \\
\hline 2002 & $-41,8$ & 4,85 & 1,4 \\
\hline 2003 & $-46,6$ & 6,08 & 3,9 \\
\hline 2004 & $-45,3$ & 5,15 & 5,3 \\
\hline 2005 & $-46,7$ & 3,99 & 3,6 \\
\hline 2006 & $-47,1$ & 3,59 & 6,2 \\
\hline 2007 & $-44,2$ & 1,85 & 6,8 \\
\hline 2008 & $-46,6$ & 3,63 & 5,1 \\
\hline 2009 & $-49,8$ & 7,32 & 1,6 \\
\hline 2010 & $-53,60$ & 7,63 & 3,9 \\
\hline 2011 & $-54,80$ & 4,90 & 4,5 \\
\hline 2012 & $-54,40$ & 3,74 & 2,0 \\
\hline 2013 & $-55,70$ & 4,02 & 1,6 \\
\hline 2014 & $-50,10$ & 3,20 & 3,3 \\
\hline
\end{tabular}

Observing the dynamics of economic growth in Poland since 2000 we notice that while in 2000 recorded the growth of $4.3 \%$, in 2001-2002 there was a drop in GDP and fluctuated between $1.2-1.4 \%$. In subsequent years 2003-2006, GDP in Poland was on a path of moderate growth reaching even in 2006 the level of $6.2 \%$. Analyzing the level of GDP in Poland, especially in the period approaching the financial crisis it must be noted that from 2007 onwards. Until mid-2008 observed a relatively high level of GDP, oscillating in individual quarters in the range from $7.5 \%$ to $6.1 \%$ and the average from $6.8 \%$ in 2007 to $5.2 \%$ in 2008 in the second half of 2008 it was seen a significant slowdown in economic growth (GDP in 2009 increased by about 1.8 The years 2010 - 2014 was a period of many changes in GDP growth because, while in 2011 was an increase of $4.5 \%$, already in 2013 - a decrease of $1.6 \%$ (Table 2). In turn, Table 3 presents the percentage changes of selected variables - current year to the previous year (R1-R0) / R0).

Table 3 Percentage changes of selected variables in Poland (change year to year)

\begin{tabular}{c|c|c|c|c}
\hline Year & $\begin{array}{c}\text { Public } \\
\text { finances } \\
\text { revenue_ } \\
\text { real }\end{array}$ & $\begin{array}{c}\text { Public } \\
\text { finances } \\
\text { expenditure } \\
\text { real }\end{array}$ & $\begin{array}{c}\text { GG debt_ } \\
\text { real }\end{array}$ & $\begin{array}{c}G G \\
\text { deficit_real }\end{array}$ \\
\hline 2001 & 1,71 & 6,61 & 1,35 & 59,34 \\
\hline 2002 & 2,63 & 4,50 & 14,14 & 3,32 \\
\hline 2003 & 4,09 & 3,18 & 15,40 & 29,79 \\
\hline 2004 & 4,46 & 2,59 & 2,90 & $-10,17$ \\
\hline 2005 & 8,25 & 4,04 & 7,19 & $-19,52$ \\
\hline 2006 & 8,87 & 6,37 & 8,16 & $-3,62$ \\
\hline 2007 & 12,51 & 6,50 & 1,93 & $-43,93$ \\
\hline 2008 & 1,96 & 6,41 & 8,95 & 102,50 \\
\hline 2009 & 1,27 & 6,41 & 10,10 & 107,71 \\
\hline 2010 & $-0,49$ & 5,04 & 10,72 & 7,33 \\
\hline 2011 & 5,15 & $-0,43$ & 5,99 & $-33,42$ \\
\hline 2012 & 3,89 & 0,67 & $-0,54$ & $-23,52$ \\
\hline 2013 & $-1,03$ & 0,51 & 4,47 & 9,43 \\
\hline 2014 & 4,13 & 2,53 & $-6,44$ & $-17,22$ \\
\hline
\end{tabular}

The variables presented in the table are in real terms by the CPI $\left(I_{1}=2000=100\right)$. Analyzing the results in Table 3 , we note that in 2007, in Poland has performed a significant increase (change of $12.51 \%$ ) of government revenues (compared to 2006), the increase in spending of public finances (change of $6.5 \%$ ), and slight decline in public debt and a significant decrease in the deficit of General Government (change of $-43.93 \%$ ), with sustained high economic growth of $6.8 \%$ of GDP. During the crisis, there was a slight increase in government revenues $(1.96 \%)$ in 2008 compared to 2007 , the increase in spending of public finances (change of $6.41 \%$ ), the increase in public debt (change of $8.95 \%$ ) and a significant increase in the GG deficit (change of $102.5 \%$ ), with slightly lower, but still high GDP growth rate $(5.1 \%)$. In turn, the year 2009 was characterized by low economic growth of $1.6 \%$ of GDP with a much lower gain public revenues (change of $1.27 \%$ ) compared to 2008., increased spending of public finances (change of $6.41 \%$ ), a higher deficit (change of $10.10 \%$ ) and public debt (change of $107.71 \%$ ) compared to the previous year. However, in 2014 (compared to 2013) observed decrease in the deficit (change of $-17.22 \%$ ) and public debt (change of $-6.44 \%$ ) with an increase in public revenue (change of $4.13 \%$ ) and growth public expenditure (change of $2.53 \%$ ). On the other hand, economic growth in 2014 was higher $(3.3 \%$ GDP) compared to $1.6 \%$ of GDP in 2013. It seems that it is difficult to indicate at which point there were strictly Keynesian and non-Keynesian 
effects of fiscal tightening in Poland in the period under review. This is partly due to the fluctuations koninkturalnych as gopodarcze slowdown of 2001-2002 and the recent financial crisis, which began in 2008 .

\section{Conclusions}

The considerations discussed in this article focus on the relationship between the deficit and the debt of public finance sector and economic growth in Poland. The deficit and public debt are the key indicator of the direction of fiscal policy in the country. The time of the restrictive fiscal policy necessary to reduce the level of debt was interrupted in 2008 with the arrival of the global financial crisis. As a result, in 2009-2010, many countries applied expansive fiscal stimulus, which had a base in the Keynesian approach to stimulate the economy. In Poland, even before the crisis was limited deficit and public debt, with high economic growth, while during the crisis increased the imbalance of public finance at a lower rate of economic growth. It was only from 2011 began the process of tightening fiscal policy which the effects of improving public finances, with moderate growth (3.3\% of GDP), is visible only from 2014. Expansionary fiscal policy often caused by economic fluctuations contributes to the deepening of public finance imbalance with frequent decline in GDP growth. The restrictive policy influences on improving the situation of the public finance sector in the long-term with at least moderate economic growth.

\section{References}

[1] Mackiewicz M., Stabilizacyjna polityka fiskalna $w$ krajach OECD, PWE Warsaw 2010, p.51.

[2] Stawska J., Wplyw policy-mix na wzrost gospodarczy $i$ poziom bezrobocia $w$ Polsce, "Zeszyty Naukowe No. 804, Finanse, Rynki finansowe, Ubezpieczenia" No. 67, University of Szczecin, 2014, p.673.

[3] Talvi E., Vegh C. A., Tax base variability and procyclical fiscal policy, NBER Working Paper, Cambridge, 2000.

[4] Lane P., The Cyclical Behavior of Fiscal Policy: Evidence from the OECD, "Journal of Public Economics", nr 87,2003, pp. 2661-2675.

[5] Alesina A., Tabellini G., Why is Fiscal Policy often Procyclical? NBER Working Paper, 2005, No. 11600.

[6] Adam C., Bevan D., Fiscal deficits and growth in developing countries, "Journal of Public Economics", 2005, No. 89, pp. $571-597$.

[7] Reinhart C. M., Rogoff K. S., Growth in a time of debt, "NBER Working Paper", 2010, No. 15639.

[8] Bukowski S.I., Czy gospodarka może funkcjonować bez dlugu publicznego? IX Congress of Polish Economists, 2013, pp. $2-3$.

[9] Rzońca A., Czy Keynes się pomylit? Skutki redukcji deficytu w Europie Srodkowej, Scientific Publishing SCHOLAR, Warsaw 2007, pp. 32 - 56; 115-116.

[10] Rzońca A., Niekeynesowskie skutki zacieśniania polityki fiskalnej. Zmodyfikowany model Blancharda. Cześś I, "Bank i Kredyt" No. 10/2004, pp. 41-42; 53-54.

[11] Blanchard O.J., Debt, deficits, and finite horizons, The Journal of Political Economy, No. 93(2), 1985.
[12] Blanchard O.J., Comment on Giavazzi and Pagano, NBER Macroeconomics Annual, 1990.

[13] Rzońca A., Niekeynesowskie skutki zaciesniania polityki fiskalnej. Zmodyfikowany model Blancharda. Część II, "Bank i Kredyt" No. 11-12/2004, p. 24.

[14] Alesina A., Perotti R., Fiscal Adjustments in OECD Countries: Composition and Macroeconomic Effects, NBER Working Paper, No. 5730, National Bureau of Economic Research, Cambridge, August 1996.

[15] Alesina A., Ardagna S., Tales of fiscal adjustment, Economic Policy: A European Forum, Vol. 27, October 1998, pp.487-546.

[16] Alesina A., Ardagna S., Perotti R., Schiantarelli F., Fiscal policy, profits, and investment, American Economic Review 92(3), 2002, pp. 571-589.

[17] Traktach o Unii Europejskiej Dz. U. C191 z 29. 7.1992 .

[18] Konstytucja RP, Dz. U. z 1997 r. No. 78, poz. 483 and others.

[19] Ustawa o finansach publicznych, Dz. U. 2013 poz. 85, art.74. 